\title{
Engaging Visitors in Museums with Technology: Scales for the Measurement of Visitor and Multimedia Guide Experience
}

\author{
Mohd Kamal Othman, Helen Petrie, and Christopher Power \\ Human Computer Interaction Research Group, \\ Department of Computer Science, \\ University of York, \\ Heslington East YO10 5GH UK \\ \{kamal, Helen.Petrie, cpower\}@cs.york.ac.uk
}

\begin{abstract}
Mobile technologies such as multimedia guides (MMGs) are now an important part of the visitor experience in museums and other cultural spaces. We report the development of two scales to measuring visitors' museum experiences: the Museum Experience Scale (MES) and the Multimedia Guide Scale (MGS); these quantitative measures can helpfully complement qualitative information about visitor experience. A standard psychometric methodology was used in the development of these scales: from a large set of potentially relevant statements, 57 were chosen and 255 people rated a museum experience (102 of whom had used a multimedia guide). A Principal Components analysis yielded a four factor solution for the MES (Engagement, Knowledge/Learning, Meaningful Experience and Emotional Connection) and a three factor solution for the MMGS (General Usability, Learnability and Control, Quality of Interaction). Comparing respondents who used a MMG during their museum visit with those who did not, there was a significant difference on the Engagement component of the MES, with respondents who used a MMG being significantly more engaged. The other components of the MES did not show significant differences.
\end{abstract}

Keywords: Museums, cultural spaces, user experience, multimedia guides, audio guides.

\section{Introduction}

Museums and other cultural institutions such as art galleries, historic houses, and archeological sites, referred to in this paper as cultural spaces, have been using various technologies to improve their visitors' experiences for nearly 60 years. The Stedlijk Museum in Amsterdam was the first museum to use a handheld guide in their exhibitions in 1952 [1]. It took nearly a decade before other cultural spaces followed that example, with the American Museum of National History adopting the "Sound Trek" audio guide in 1961. In addition, a Sony Walkman type system was created for the famous "Treasures of Tutankhamun" tour in the late 1970's, whilst the Louvre museum introduced the first random access guide in 1993. 
Emerging technologies such as smart phones and tablet computers are now further changing the way technologies are used in cultural spaces. In addition, the use of technology in cultural spaces is now not limited to audio commentary, but may provide diverse content types such as images, video and multimedia. A recent study found that $57 \%$ of cultural spaces surveyed in North America, Asia and Europe have adopted multimedia guides [2].

It is important for cultural spaces to embrace new technologies to engage and stimulate their visitors in exhibitions. The use of these technologies should not be regarded as replacement of the curated tour or more traditional means to disseminate information, but instead as further ways to connect and engage visitors with objects, collections and exhibits. Wasserman argues that the use of mobile technology is more than an information-distribution platform, and that it should instead connect visitors with each other, with the institution playing an important role of bringing people together through shared experiences [3].

Further, Pekarik argues that in order to have diverse and exciting cultural spaces in the future there must be investigation through rigorous methods on how to increase the range of satisfying experiences had by visitors [4]. Clearly, technology can play a major role in helping to create those experiences. However, if technology is not developed and deployed carefully it is likely that technology could detract from the visitors' experience. Therefore, it is important to develop methods and measures for determining the nature, valence and size of the effects that technology has on visitors' experiences in cultural spaces.

There are many examples measuring different aspects of user experience that are useful for studying technology in the cultural spaces domain. The acceptance of technology by users, a multi-dimensional concept comprised of perceived ease of use and perceived usefulness of the technology, was originally proposed by Davis and studied in many different domains [5]. These factors are also discussed in work on cognitive absorption [6]. There are examples of measuring immersion, the feeling of being pulled into and becoming lost in the interaction with a piece of technology [7, 8], and qualitative work in examining the engagement of visitors with interactive exhibits [9]. Finally, there is flow [10], the concept of optimal experience where a user experiences feelings of satisfaction and achievement when the experience is complete. This, too, has been examined in many different contexts $[11,12,13]$. However, none of these measures, as defined in previous work, have been developed specifically for the cultural spaces domain. In this paper, we build on previous work on user experience to create measurement scales for this domain to quantify the effect that the use technology has on visitors.

This study was designed to investigate the effects of multimedia guides on the experiences of visitors to cultural spaces. We will take both a qualitative and quantitative approach to this question. We are developing standard questionnaires to measure both visitors' overall experience, particularly the engagement, with the exhibition (the Museum Experience Scale, henceforth MES) and the usefulness and usability of multimedia guides (the Multimedia Guide Scale, henceforth MMGS). We have presented initial findings on the MES [14] that produced four factor structure, here we present the final form and the MMGS.

This paper will outline the full development of the two scales, and results of an initial use of the MES, as well as plans for further development of the research. 


\section{Method}

\subsection{Scale Development}

The development of the two questionnaires followed standard psychometric scale development $[14,15]$. Initially, a large set of topics, ideas and statements were collected by reviewing relevant previous studies and papers $[5,8,9,16,17,18,19]$ and materials developed by the UK Council for Museums, Libraries and Archives. The Generic Learning Outcomes model developed by the MLA [18] was particularly useful in developing the range of statements. This process resulted in 152 potential statements for the scales ${ }^{1}$. Three evaluators then used a consensus process to reduce the number of statements by grouping them into themes and removing similar or overlapping statements. This resulted in 57 statements: 37 for the MES and 20 for the MMGS. The items were presented in the scales as Likert items from 1 meaning "strongly disagree" to 5 meaning "strongly agree".

\subsection{Procedure}

The initial versions of the two scales were presented online using QuestionPro ${ }^{2}$ survey software. The study was widely publicized via numerous email lists and an advertisement on Facebook. Publicity asked for people who had visited a museum in the past six months, with or without a multimedia guide. To encourage participation, a prize draw for Amazon gift vouchers was offered to all participants.

All participants completed the initial version of the MES and of the MMGS if they had used a multimedia or audio guide on their museum visit. In addition, they also completed a short questionnaire to gather information about their museum visit (which museum, how long the visit lasted, how many people in the party etc), as well as standard demographic information.

\subsection{Participants}

255 participants completed the scales. 96 were male, 175 were female. Participants came from very diverse backgrounds (e.g. country of residence, education or work background, age). This should help to ensure a robust scale. 102 respondents had used multimedia guide during their museum visit, 153 participants had not.

\section{Results}

For each scale, a principal components analysis was performed on the ratings of the statements to extract the components or groups of questions that elicit similar responses from participants.

\footnotetext{
${ }^{1}$ The set of potential statements is available at: these are available at www.cs.york.ac.uk/hci/docs/inital_items.pdf

2 http : / / www . questionpro.com/
} 
Table 1. The 4 components of the Museum Experience Scale (MES) and their factor loadings

\begin{tabular}{|c|c|c|c|}
\hline \multicolumn{2}{|l|}{$\begin{array}{r}\text { Engagement } \\
\end{array}$} & \multicolumn{2}{|l|}{ Knowledge/Learning } \\
\hline I enjoyed visiting the exhibition & 0.69 & $\begin{array}{l}\text { The information provided about the } \\
\text { exhibits was clear }\end{array}$ & 0.64 \\
\hline I felt engaged with the exhibition & 0.69 & $\begin{array}{l}\text { I could make sense of most of the } \\
\text { things and saw and did at the } \\
\text { exhibition }\end{array}$ & 0.57 \\
\hline $\begin{array}{l}\text { My visit to the exhibition was very } \\
\text { interesting }\end{array}$ & 0.68 & $\begin{array}{l}\text { I liked graphics associated with the } \\
\text { exhibition }\end{array}$ & 0.52 \\
\hline $\begin{array}{l}\text { I felt I was experiencing the } \\
\text { exhibition, rather than just visiting } \\
\text { it }\end{array}$ & 0.65 & $\begin{array}{l}\text { My visit enriched my knowledge } \\
\text { and understanding about specific } \\
\text { exhibits }\end{array}$ & 0.52 \\
\hline $\begin{array}{l}\text { My visit to the exhibition was } \\
\text { inspiring }\end{array}$ & 0.56 & $\begin{array}{l}\text { I discovered new information from } \\
\text { the exhibits }\end{array}$ & 0.43 \\
\hline \multicolumn{2}{|l|}{$\begin{array}{l}\text { Meaningful Experience } \\
\end{array}$} & \multicolumn{2}{|l|}{$\begin{array}{r}\text { Emotional Connection } \\
\end{array}$} \\
\hline $\begin{array}{l}\text { During my visit I was able to reflect } \\
\text { on the significance of the exhibits } \\
\text { and their meaning }\end{array}$ & 0.74 & $\begin{array}{l}\text { The exhibition enabled me to } \\
\text { reminisce about my past }\end{array}$ & 0.55 \\
\hline $\begin{array}{l}\text { During my visit, I put a lot of effort } \\
\text { into thinking about the exhibition }\end{array}$ & 0.53 & $\begin{array}{l}\text { My sense of being in the exhibition } \\
\text { was stronger than my sense of } \\
\text { being in the real world (reversed } \\
\text { relationship) }\end{array}$ & 0.52 \\
\hline $\begin{array}{l}\text { Seeing rare exhibits gave me a } \\
\text { sense of wonder about the } \\
\text { exhibition }\end{array}$ & 0.50 & $\begin{array}{l}\text { I was overwhelmed with the } \\
\text { aesthetic/beauty aspect of the } \\
\text { exhibits }\end{array}$ & 0.47 \\
\hline $\begin{array}{l}\text { After visiting the exhibition, I was } \\
\text { still interested to know more about } \\
\text { the topic of the exhibition }\end{array}$ & 0.43 & $\begin{array}{l}\text { I wanted to own exhibits like those } \\
\text { that I saw in the exhibition }\end{array}$ & 0.45 \\
\hline $\begin{array}{l}\text { Seeing real exhibits of importance } \\
\text { was most satisfying aspect of my } \\
\text { visit to the exhibition }\end{array}$ & 0.43 & I felt connected with the exhibits & 0.45 \\
\hline
\end{tabular}

The MES produced four components:

- Engagement with the exhibitions and exhibits

- Knowledge/Learning gained from the exhibition and exhibits

- Meaningful Experiences from the interaction with the exhibitions/exhibits and/or other visitors

- Emotional Connection with the exhibits/exhibitions

Factor loadings on the top questions for each component are shown in the Table 1, below. A factor loading is a measure of how strongly each statement relates to the overall component $(1.0=$ perfect relationship to $0.0=$ no relationship at all, only statements with factor loading over 0.43 are listed). From this analysis, a final selection of 20 questions ( 5 questions for each component) for the MES was made. For example, if two of more similar statements were in the same category, the statement with the higher factor loading was selected. 
Table 2. The 3 components on the Multimedia Guide Scale (MMGS) and their factor loadings

\begin{tabular}{|l|l||l|l|}
\hline \multicolumn{2}{|c||}{ General Usability } & \multicolumn{2}{c|}{ Learnability and Control } \\
\hline $\begin{array}{l}\text { I will use an multimedia guide } \\
\text { again when I visit an exhibition } \\
\text { (negative correlation) }\end{array}$ & 0.76 & $\begin{array}{l}\text { I felt I was in control of the } \\
\text { multimedia guide }\end{array}$ & 0.78 \\
\hline $\begin{array}{l}\text { The multimedia guide was a } \\
\text { distraction }\end{array}$ & 0.74 & $\begin{array}{l}\text { Learning to operate the multimedia } \\
\text { guide was easy }\end{array}$ & 0.74 \\
\hline $\begin{array}{l}\text { The information given by the } \\
\text { multimedia guide was too lengthy }\end{array}$ & 0.73 & $\begin{array}{l}\text { Using the multimedia guide did not } \\
\text { require much training }\end{array}$ & 0.70 \\
\hline $\begin{array}{l}\text { It was difficult to determine } \\
\text { where I was in the exhibition with } \\
\text { the multimedia guide }\end{array}$ & 0.68 & $\begin{array}{l}\text { The controls of the multimedia } \\
\text { guide were difficult to understand } \\
\text { (negative correlation) }\end{array}$ & 0.64 \\
\hline $\begin{array}{l}\text { The multimedia guide helped me } \\
\text { to navigate around the exhibition } \\
\text { (negative correlation) }\end{array}$ & 0.67 & $\begin{array}{l}\text { The multimedia guide presented } \\
\text { information in an understandable } \\
\text { manner }\end{array}$ & 0.54 \\
\hline $\begin{array}{l}\text { Using the multimedia guide } \\
\text { enhanced my exhibition visit } \\
\text { (negative correlation) }\end{array}$ & 0.65 & $\begin{array}{l}\text { I found it difficult to read the text } \\
\text { on the screen of the multimedia } \\
\text { guide (negative) }\end{array}$ & 0.53 \\
\hline $\begin{array}{l}\text { The multimedia guide was } \\
\text { complicated to use }\end{array}$ & 0.51 & & \\
\hline $\begin{array}{l}\text { It was difficult to select the option } \\
\text { I wanted with the multimedia } \\
\text { guide }\end{array}$ & 0.51 & & \\
\hline Quality of interaction with the Guide & & & \\
\hline $\begin{array}{l}\text { The multimedia guide clearly } \\
\text { provided feedback about my } \\
\text { actions }\end{array}$ & 0.72 & & \\
\hline $\begin{array}{l}\text { It was clear to me when the } \\
\text { multimedia guide was taking the } \\
\text { initiative to offer me information } \\
\text { and when I needed to ask it for } \\
\text { information }\end{array}$ & 0.54 & & \\
\hline $\begin{array}{l}\text { I became unaware that I was even } \\
\text { using any controls on the } \\
\text { multimedia guide }\end{array}$ & 0.48 & & \\
\hline
\end{tabular}

The principal components analysis for the MMGS yielded three components:

- General usability of the multimedia guide, for example whether the functionality of the guide is appropriate, whether it is easy to use

- Learnability and control, whether the guide is easy to learn to use, whether the user felt in control, and whether the information presented in a meaningful ways

- Quality of interaction with the guide, this is often considered part of usability or user experience, but interestingly in this scale, the aspects concerning interaction with and feedback from the guide form a separate component 
Table 2 shows the statements that relate to each component and their factor loadings. The questions that are labelled "negative correlation" mean that high ratings on those questions are associated with low scores on the scale.

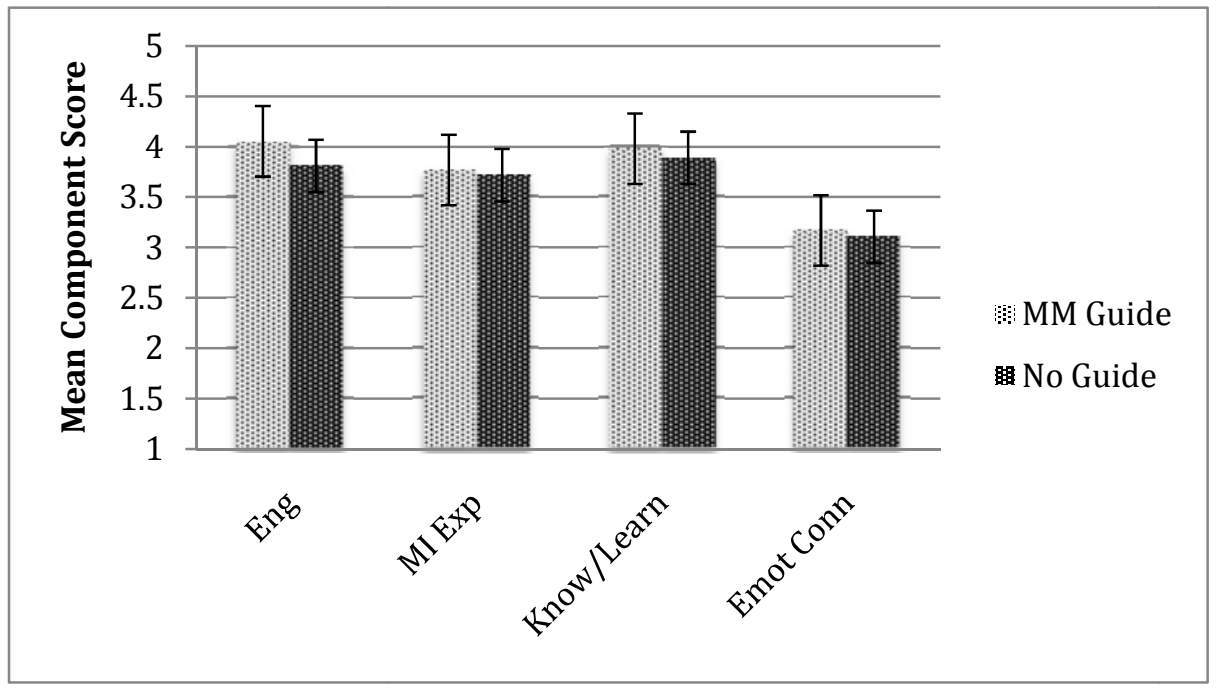

Fig. 1. Mean scores on the four components for multimedia guide and non-guide users

As an initial use of the MES, we compared the experience of participants who had made their museum visit with a multimedia guide with the experience of those who had made their visit without a multimedia guide. There was an overall significant difference in scores between two groups of participants (Analysis of variance $\mathrm{F}_{1,253}$ $=3.66, \mathrm{p}<0.05)$. There was also a significant difference between the four factors $(\mathrm{F}=$ 149.50 , df $=3,759, \mathrm{p}<0.001)$. There was no interaction between the group and factor variables.

Figure 1 shows the mean scores on the four MES components for multimedia guide and non-guide users. This shows that scores on all four components were higher (i.e. more positive) with a guide, although that difference was only significantly higher on the Engagement component, with multimedia guide users being significantly more engaged than non-guide users (Tukey's HSD p < 0.05). The lack of significant difference on the other three components is interesting in itself. This shows that the use of a multimedia guide has no effect, positive or negative on the Knowledge and Learning, Meaningful Experience, or Emotional Connection about an exhibition for museum visitors.

\section{Discussion and Conclusions}

This study has developed two scales for use in the evaluation of visitors' experiences of museums and other cultural spaces. We are not suggesting that these are the only instruments that are needed in the evaluation of such visitor experiences, but that they 
can be a useful part of an "evaluation toolkit" available to personnel responsible for evaluations. Particularly as mobile technologies such as multimedia guides become an integral part of the museum and cultural space experience, it is important to have tools available to assist in their evaluation.

The Museum Experience Scale (MES) produced four components: Engagement, Meaningful Experience, Knowledge/Learning and Emotional Connection. These are slightly different components from those we found from the initial analysis of data [14], but the current structure is based on a much larger and more robust sample of respondents. It is interesting that only the Engagement component produced a significant difference between multimedia guide users and non-users. Thus use of a multimedia guide appears to enhance engagement and does not detract from a meaningful experience of emotional connection with the exhibition.

Clearly the sense and level of engagement with exhibitions and exhibits in museums varies between visitors. Prior knowledge, motivation, interest, technology, and time spent in the exhibition may influence engagement. The findings from our study show that introducing technologies such as multimedia guides are achieving their aim, to make the museum experience more engaging for visitors. This finding supports previous research that the use of handheld devices such as multimedia guides is more appealing to visitors than more conventional and traditional ways of presenting information [18].

Although this study was a useful contribution in quantifying user experience in museums with and without multimedia guides, it had several limitations. In particular, respondents were asked about museum experiences that might be six months old, which was not ideal. To address this and several other issues, we now planning a study that will use the two scales in an on-site study of visitor experience with an archeological exhibition. This will allow us to collect data immediately after the visitor experience and to concentrate on the experience in one particular museum. Later research will be able to investigate and compare other types of museum and cultural spaces and other types of technology. In our next study, we will use two different forms of multimedia guide to investigate how differences in the presentation of the guide can affect visitors' experience of a museum or cultural space. We will also compare this with other measures of visitor experience such as short interviews.

\section{References}

1. Tallon, L.: Introduction: Mobile, Digital and Personal. In: Tallon, L., Walker, K. (eds.) Digital Technologies and the Museum Experience: Handheld Guides and Other Media. Altamira Press (2008)

2. Petrie, M., Tallon, L.: The iPhone effect?: Comparing Visitors' and Museum Professionals Evolving Expectations Mobile Interpretation Tools. In: Trant, J., Bearman, D. (eds.) Museums and the Web 2010. Archives and Museums Informatics, Toronto (2010)

3. Wasserman, S.: Beyond Information: Ritual, Relationship and Re-encounter through Mobile Connectivity. Curator: The Museum Journal 54, 11-24 (2011)

4. Pekarik, A.J.: The Long Horizon: The Shared Value of Museums. Curator: The Museum Journal 54, 75-78 (2011)

5. Davis, F.D., Bagozzi, R.P., Warshaw, P.R.: User Acceptance of Computer Technology: A Comparison of Two Theoretical Models. Management Science 35, 982-1003 (1989) 
6. Agarwal, R., Karahana, E.: Time Flies When You're Having Fun: Cognitive Absorption and Beliefs about Information Technology Usage. MIS Quarterly 24, 465-694 (2000)

7. Cheng, K., Cairns, P.A.: Behaviour, Realism and Immersion in Games. In: CHI 2005 Extended Abstracts on Human Factors in Computing Systems. ACM Press, Portland (2005)

8. Haywood, N., Cairns, P.: Engagement with an Interactive Museum Exhibit. In: People and Computers XIX - The Bigger Picture. Springer, Heidelberg (2005)

9. Jennett, C., Cox, A.L., Cairns, P., Dhoparee, S., Epps, A., Tijs, T., Walton, A.: Measuring and Defining the Experience of Immersion in Games. International Journal of Human Computer Studies 66, 641-661 (2008)

10. Csikszentmihalyi, M.: Flow: The Psychology of Optimal Experience. Harper and Row, New York (1990)

11. Chen, H., Wigand, R.T., Nilan, M.: Optimal Flow Experience in Web Navigation: Effective Utilization and Management of Emerging Information Technologies. In: Ninth Information Resources Management Association Conference. Idea Group Publishing, USA (1998)

12. Rettie, R.: An Exploration of Flow during Internet Use. Internet Research: Electronic Networking Applications and Policy 11, 103-113 (2001)

13. Gaggioli, A., Bassi, M., Delle Fave, A.: Quality of Experience in Virtual Environments. In: Riva, G., Davide, F., Ijsselstijn, W.A. (eds.) Being There: Concepts, Effect and Measurement in User Presence in Synthetic Environments. IOS Press, Amsterdam (2003)

14. Othman, K., Petrie, H., Power, C.: Understanding visitors' experiences with multimedia guides in cultural spaces. In: Aljaset, A., et al. (eds.) Proceedings of Transforming Culture in the Digital Age. University of Tartu, Tartu (2010)

15. Anastasi, A., Urbina, S.: Psychological Testing, 7th edn. Prentice Hall, Upper Saddle River (1997)

16. DeVellis, R.F.: Scale development: theory and applications, 2nd edn. Sage Publications, London (2003)

17. Naismith, L., Sharples, M., Ting, J.: Evaluation of CAERUS: A Context Aware Mobile Guide. In: mLearn 2005, Cape Town (2005)

18. Naismith, L., Smith, P.M.: Using Mobile Technologies for Multimedia Tours in a Traditional Museum Setting. In: mLearn 2006, Canada (2006)

19. MLA. Inspiring Learning for All, Museum and Libraries Association, http: / /www. inspiringlearningforall.gov.uk

20. Pekarik, A.J., Doering, Z., Karns, D.A.: Exploring Satisfying Experiences in Museums. Curator: The Museum Journal 42, 117-129 (1999)

21. Boehner, K., Gay, G., Larkin, C.: Drawing Evaluation into Design for Mobile Computing: A Case study of the Renwick's Gallery's Hand Held Education Project. International Journal of Digital Libraries 5, 219-230 (2005) 